\title{
Listening Skills for Learning German Using Blended Learning Models
}

\author{
Risnovita Sari ${ }^{1}$, Rina Evianty ${ }^{2}$, Muhammad Amran ${ }^{3}$ \\ ${ }^{1,2,3}$ Universitas Negeri Medan, Medan, Indonesia \\ risnovita1801@gmail.com
}

\begin{abstract}
Abstarct: Listening skills are one of the skills in learning German. Listening skills are also a very important skill in the learning process to improve German language skills. The ability to actively listen is defined as the process of actively understanding to get information, and the attitude of the speaker whose purpose is to understand the conversation objectively. In the current era of globalization many online learning methods have been applied, one of which is the Blended Learning model. Blended Learning is a combination of face-to-face learning and online learning.
\end{abstract}

Keywords: Listening skills; German Learning; blended learning.

\section{Introduction}

In the era of the industrial revolution 4.0 the use of online learning methods is needed, one of which is Blended Learning. Blended Learning is a combination of face-to-face learning and online learning. Learning can also be accessed through Portals, Blogs, Websites and social media. It is also recommended to use E-Learning, because there are many advantages when compared to other learning models. Garrison (2008: 6) argues that "Blended Learning is the right blend of learning experiences and online. That means that Blended Learning is an appropriate combination of face-to-face learning and online learning.

Listening skill is one of language skills. Listening is a person's ability to understand words or phrases mentioned by the interlocutor or certain media. The subject of listening comprehension aims to give students good listening skills with verbal and written answers, based on various types of dialogue texts and monologue texts that are heard.

Based on the author's experience and observations, there are still many students at Medan State University who experience difficulty in listening during the course. Students also still know a little vocabulary in German. This makes students unable to understand the core of the video shown, and cannot answer the practice questions properly.

\subsection{Definition of Listening}

\section{Review of Literature}

Myers and Myers (1999: 143) state that listening not only hears, but also includes an additional dimension of understanding, paying attention, analyzing, and evaluating verbal messages, and perhaps acting on the basis of what has been heard. Likewise, Floyd, as quoted by Myers and Myers, defines the recipient's listening orientation for the communication process, because communication involves both source and receiver. Rost (1994: 2) states that listening is a process that is triggered by our attention. In psychological terms, attention is the excitation of the neural pathways, the brain, to regulate stimuli that enter in an efficient way. Farlex (2007: 2) defines that listening is an act of listening attentively.

According to Courtland and John (2013: 66) accepting is the most important skill needed to complete work at work. Listening effectively supports the organization, increases product delivery, prepares the organization to provide opportunities, and allows the organization to manage in an era marked by facilitating workforce and customer competencies that support the company. Effective listening is very important in the process of 
building trust not only between organizations, but also between individuals. Understanding the nature of listening is the first step towards improving listening skills, which affect what they hear and the meaning they absorb. People-oriented listeners may miss important clues about impending deadlines, while action-oriented listeners may miss important clues that there are personal problems that are heating up between two members. When you read about common types of listening, reflect on your tendencies as a listener, and consider how learning to use certain methods can make your listening activities more effective.

Here are 3 types of listening:

a. Listening to content (listening content) is understanding and mastering the speaker's message. Listening to the contents of the conversation, the emphasis is on information and understanding. You can ask a number of questions to clarify the material. You try to ignore the style of conversation and any limitations in conveying it, focus only on the information.

b. Critical listening is understanding and evaluating the meaning of the speaker's message at several levels: logical argument, strong evidence, valid conclusions, message implications for you and your organization, the intent and motives of the speaker, and any relevant information or points that was eliminated. When in doubt, ask questions to investigate the speaker's perspective and credibility. Pay attention to speakers who might color the way information is conveyed, and be careful to always separate opinions from facts.

c. Emphatic listening is understanding the speaker's feelings, needs, and desires so that you can appreciate his perspective, regardless of whether you have the same perspective with him. By listening by showing empathy, you help the individual release emotions that prevent an intelligent and calm approach to the subject.

\subsection{Concept of Learning}

Winkel (1991: 53) states that learning is a psychic mental activity that takes place in active interaction with the environment, resulting in changes in knowledge, understanding, skills, values and attitudes. These changes are relatively constant and fluid.

Brown (2000: 7) defines learning in the sphere of seven spheres, namely: (1) Learning is the acquisition or acquisition, (2) Learning is the retention of information or skills, (3) Retention includes systems of storage, memory and cognitive organization, (4) Learning involves actively and consciously focusing and taking action on events inside and outside the organism, (5) Learning is relatively permanent but is a subject to be forgotten, (6) Learning involves some form of training, and (7) Learning is a change behavior.

In learning there are five components as presented by Dick and Carey in Sukamto (1993: 21) namely: (1) Pre-learning activities, (2) Information sharing, (3) Student participation, (4) Assessment, and (5) Activities advanced. Thus, learning encompasses the whole process of teaching learning that involves all elements and components of learning: students, teachers, curriculum, media and strategies and the environment.

From the various opinions about learning above, it can be concluded that learning is a process that involves mental, psychological and cognitive to obtain knowledge, value skills or new attitudes / behaviors that are relatively permanent and permanent as a result of environmental stimulation. This conclusion clarifies the relationship of learning with the definition of learning mentioned in the 2003 National Education System Law. Accordingly, 
Gagne and Briggs as quoted by Sadiman (1993: 38) suggest that learning is a series of activities that affect students in such a way that the learning process can take place with easy.

In learning there are five components as stated by Dick and Carey in Sukamto (1993: 21), namely: (1) Pre-learning activities, (2) Submission of information, (3) Student participation, (4) Assessment, and (5) Activities advanced. Thus, learning includes the whole teaching and learning process that involves all elements and components of learning, namely students, teachers, curriculum, media and strategies as well as the environment.

\section{Discussion}

\subsection{German as a Foreign Language in Indonesia}

German is the second foreign language after English and German becomes important to learn, this is due to the rapid development of communication technology, so that distance is not an obstacle to get information from various parts of the world. Thus it becomes increasingly clear that the mastery of a second foreign language after English, is very urgent, in this case German. Much of the scientific information in the fields of engineering, pure sciences, economics, and psychology as well as art is sourced from German books. Many ways and strategies that we can use to master foreign languages that we will learn.

In this era of globalization, the progress of science and technology is so rapid, demanding the government to make updates in the field of education. This can be seen by the enactment of the 2006 Education Unit Level Curriculum (KTSP). To support the successful implementation of the KTSP, an approach has also been called the Contextual Teaching and Learning.

There is a tendency today to return to the idea that children will learn better if the environment is created naturally. Learning will be more meaningful if the child "experiences" what he is learning, not knowing it. Target-oriented learning mastery of the material proved successful in the competition given the short term, but failed to equip children to solve problems in long-term life.

According to Ur (1996: 4-5) the success of a foreign language teaching program is influenced by various factors, including the method. The language teaching method is defined as all activities, assignments and other learning experiences developed by the teacher in the classroom in the language teaching process. In that sense, the language teaching method is seen from the perspective of procedural aspects in the classroom. This aspect only covers all strategic or procedural ways developed by the teacher to help students learn a lesson or subject. Complementing this understanding, Nunan (1990: 65) defines language teaching methods as activities, procedures and principles or theories that underlie those believed and implemented by teachers in the organization of language teaching programs.

\subsection{Definition of Blended Learning}

Blended learning consists of words blended (combination / mixture) and learning (learning). Another term that is often used is hybrid course (hybrid = mix / combination, course $=$ course). The original meaning as well as the most common blended learning refers to learning that combines or mixes between face to face learning (face to face $=\mathrm{f} 2 \mathrm{f}$ ) and computer based learning (online and offline). Thorne (2003) describes blended learning as "it represents an opportunity to integrate the innovative and technological advances offered by 
online learning with the interaction and participation offered in the best of traditional learning.

Whereas Bersin (2004) defines blended learning as:

"the combination of different training "media" (technologies, activities, and types of events) to create an optimum training program for a specific audience. The term "blended" means that traditional instructor-led training is being supplemented with other electronic formats. In the context of this book, blended learning programs use many different forms of learning, perhaps complemented with instructor-led training and other live formats".

Blended learning model is a learning model that combines face to face teaching methods with computer-assisted teaching methods both offline and online to form an integrated learning approach. In the past, digital-based materials have been practiced but within the supporting role, which is to support face-to-face teaching. The purpose of blended learning is to provide the most effective and efficient learning experience.

Cheung \& Hew (2011: 1325) states blended learning is a combination of face to face learning and online learning. Uwes A. Chaeruman (2011) explains blended learning as learning that combines synchronous and asynchronous learning settings precisely in order to achieve learning objectives. Synchronous learning is learning activities carried out at the same time and in the same or different places, while asynchronous learning is learning activities carried out at different times and places (Litt Lejohn and Pegler, 2007: 51-53).

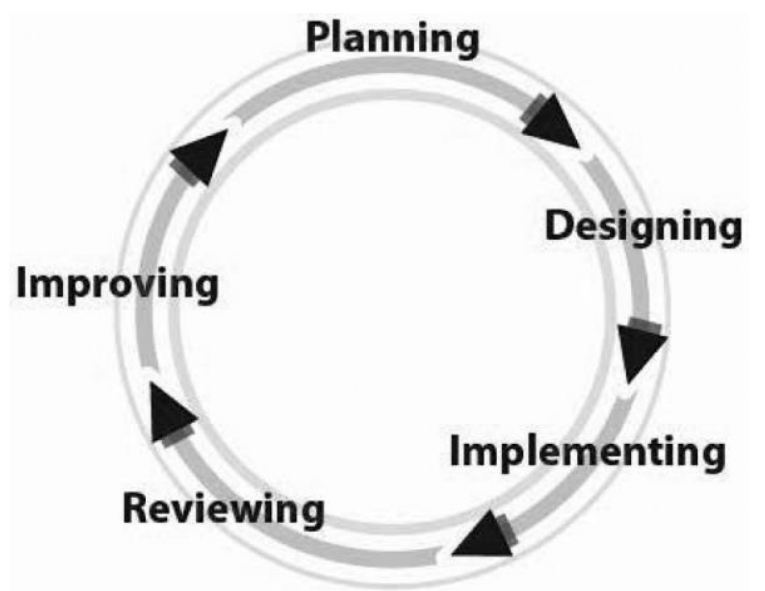

Figure 1. Learning Step of Blended Learning Model

The Bended Learning model is needed to bridge the lack of face-to-face learning and the lack of e-learning learning. Preliminary research on blended learning has been conducted by Sulihin (2012) who concluded that there is an increase in learning motivation and student learning outcomes due to the application of the blended learning model. Kazu and Demirkol (2014) in their research concluded that the blended learning model was more effectively applied in learning than the traditional model.

Blended Learning is learning that combines all forms of learning such as online learning, live with face to face (Suartama \& Tastra, 2014: 18). According to Hermawanto, Kusairi \& Wartono (2013) one of the problems faced by physics teachers in physics learning is the mastery of concepts and student reasoning is still low. For this reason, it is necessary to change the learning paradigm towards student centered oriented learning, through blended learning. Blended learning is learning that combines face-to-face learning with online 
learning. According to Garnham, the purpose of developing blended learning is to combine the best features of classroom learning (face to face) and the best features of online learning to enhance learning actively independent by students (Husamah 2013: 21).

Yusuf (2011), Blended learning is the development of e-learning models that are considered the most appropriate approach to moderate the learning needs of open societies to global changes while fulfilling traditional learning tastes that cannot be abandoned. Pradnyawati, Suparta, \& Sariyasa (2014) stated that blended learning can also facilitate a variety of student learning styles, where each student has a different learning style. Wahyuningsih (2013: 39) defines blended learning with a constructive approach. Blended learning by constructive approach (BLCA) consists of two terms, namely blended learning (mixed learning) and constructive approach (constructive approach).

\section{Conclusion}

Listening is an intellectual and emotional process. With this process people gather and integrate input, physical, emotional and intellectual from others and try to capture the message and its meaning. When you read about common types of listening, reflect on your tendencies as a listener, and consider how learning to use certain methods can make your listening activities more effective. Here are 3 types of listening: (1) The main purpose of listening to content (content listening) is to understand and master the speaker's message. (2) The main purpose of critical listening is to understand and evaluate the meaning of the speaker's message at several levels: logical argument, strong evidence, valid conclusions, message implications for you and your organization, the intent and motives of the speaker, and any information or relevant points removed. (3) The main purpose of listening with empathy (emphatic listening) is to understand the feelings, needs, and desires of the speaker so that you can appreciate his point of view, Learning covers the whole teaching and learning process that involves all elements and components of learning namely students, teachers, curriculum, media and strategy and environment.

Blended learning is a pedagogical approach that combines effectiveness with classroom socialization opportunities that technologically encourage active learning. Implementing this approach allows online learning resources to be used, especially webbased ones, without leaving face-to-face activities. With the implementation of blended learning, learning takes place more meaningfully because of the diversity of learning resources that might be obtained.

\section{References}

Alfafa, M.F., Agung, A.A.G., Tegeh, I.M. (2018). Pengembangan Blended Learning Tipe Station-Rotation Model pada Mata Pelajaran Bahasa Indonesia Kelas X Multimedia. Jurnal Jurusan Teknologi Pendidikan. IX (2) 236-245.

Asri, Wahyu Kurniati. (2010). Peningkatan Kemampuan Pembelajaran Bahasa Jerman dengan Pendekatan Pembelajaran Kontekstual pada Siswa SMA Negeri 8 Makassar. Jurnal Lingua Didaktika. IV (1) 67-73.

Arsyad, Azhar. (2015). Media Pembelajaran. Jakarta: PT Raja Grafindo Persada 
Budiharti, R., Ekawati, E.Y., Pujayanto, Wahyuningsih, D., Adilah, D.N. (2015). Kajian Kualitatif Efektivitas Blended Learning IPA Terpadu Berbasis SETS di SMP Wilayah Eks Karesidenan Surakarta. Jurnal Materi dan Pembelajaran Fisika. V(1) 3541

Idris, Husni. (2011). Pembelajaran Model Blended Learning. Jurnal Iqra', 61-73.

Ismaniati, C., Sungkono. \& Wahyuningsih, D. 2015. Model Blended Learning Untuk Meningkatkan Kemandirian Belajar Dan Daya Tarik Dalam Perkuliahan. Jurnal Penelitian Pendidikan, 19-27.

Kurniati, Rita. (2014). Pengembangan Model Pembelajaran Blended Learning pada Mata Pelajaran Keterampilan Komputer dan Pengelolaan Informasi (KKPI) Kelas $\quad$ XI di SMK Negeri2 Purwodadi.

Prastika, Yulia Dewi. (2017). Pengembangan Perangkat Blended Learning Berbasis LMS dengan Model Pembelajaran Inkuiri pada Materi Fluida Statis

Prihadi, Singgih. (2013). Model Blended Learning, Teori dan Praktek dalamPembelajaran Geografi. Surakarta: Yuma Pustaka

Rimbawati, N. and Muchlas. (2015). Pengembangan Model Pembelajaran Adaptive Blended Learning untuk Berbagai Jenis Gaya Belajar Siswa Menengah

Atas pada Pokok Bahasan Listrik Statis. Jurnal Penelitian \& Pengembangan Pendidikan Fisika, 1-6.

Sari, Ambar Wulan. (2016). Pentingnya Keterampilan Mendengar dalamMenciptakan Komunikasi yang Efektif. Jurnal EduTech, 1-10.

Sucihati, Theresia Budi. (2016). Meningkatkan Kemampuan Mendengarkan Mahasiswa dengan Cloze Dictation. Jurnal Media Prestasi, 109-125. 